Bolm Inst. oceanogr., S Paulo, 28(2):65-78, 1979

\title{
VERTICAL DISTRIBUTION OF PARACALANUS CRASSIROSTRIS (COPEPODA, CALANOIDEA): ANALYSIS BY THE GENERAL LINEAR MODEL ${ }^{1}$
}

\author{
ANA MILSTEIN ${ }^{2}, 3$
}

Instituto Oceanográfico da Universidade de São Paulo

\section{Synopsis}

The vertical distribution of each developmental stage of Paracalanus crassirostris

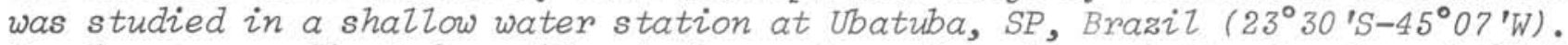
Samples were collected monthly at the surface, $2 m$ and near bottom levels. Salinity, temperature, dissolved oxygen, tide height, light penetration and solar radiation were also recorded. Data were analysed by the general linear model. It showed that the amount of individuals at any developmental stage is affected diversely by hour, depth, hour-depth interaction and environmental factors throughout the year and that these effects are stronger in summer. All developmental stages were spread in the water colum showing no regular vertical migrations. On the other hand, the number of organisms caught in a particular hour seemed to dependmore on the tide than on the animals behaviour. The results of the present paper showed, as observed by some other authors, the lack of vertical migration of a coastal copepod which is a grazer of fine particles throughout its life.

Introduction

Many studies at sea and in laboratories have been performed in order to understand and explain the vertical migration of plankton, but little is known about this phenomenon in shallow waters. Papers on VM (vertical migration) in laboratories have been written by Lewis (1959), Lance (1962), Enright \& Hammer (1967), Björnberg \& Wilbur (1968), and Grindley (1972). Researches on VM at sea, in inlet or shallow waters, have been worked out by Yamazi (1957), Jacobs (1968), Pillai \& Pillai (1973), Daro (1974), Stickney \& Knowles (1975), Furuhashi (1976) and Grindley (1977).

In Brazil, besides that of Björnberg \& Wilbur mencioned above, some other studies on VM have been performed: on total plankton (Moreira, 1976),

1 Thesis submitted to the Instituto Oceanogräfico da Universidade de São Paulo, in partial fulfillment of the requirements for the degree of Master in Biological Oceanography.

2 From September 1977 on, this work was sponsored by a fellowship given by O.E.A.

3 Present address: Museo Nacional de História Natural, Casilla 399, Montevideo, Uruguay.

Publ. no 453 do Inst. oceanogr. da usp.
Hydromedusae (Moreira, 1973), Lucifer faxoni (Jimenez, 1976), and Cladocera and Ostracoda (Rocha, 1977) at a $50 \mathrm{~m}$ depth station off Santos, and on adult Paracalanus crassirostris at Ubatuba (Milstein, in press).

Taking into account the importance of coastal waters in the productivity of the seas, the study of vertical distribution of zooplankton in shallow waters have been proposed. In this paper, the VM of each developmental stage of Paracalanus crassirostris at a $5 \mathrm{~m}$ depth station at Ubatuba is analysed throughout the year. This species was chosen because it is one of the most abundant in the tropic and subtropic belts. It is an indicator of coastal waters (Björnberg, 1963), which can be found also in inlet areas. It has been recorded from almost fresh waters up to marine ones (Sewe11, 1948); Devasundaram \& Roy, 1954; Björnberg, 1963; Teixeira, Tundisi \& Kutner, 1965; Tundisi, 1972) and of temperature between $1^{\circ} \mathrm{C}$ (Anraku, 1964) and about $30^{\circ} \mathrm{C}$ (Gurney, 1927; Grice, 1960; Björnberg, 1963; Tundisi, 1972).

Material and sampling methods

Samples were collected at a fixed station (Fig. 1) at Enseada do Flamengo, UbatubaSP $\left(23^{\circ} 30^{\prime} \mathrm{S}-45^{\circ} 07^{\prime} \mathrm{W}\right)$, in eleven days sorted out in one year (from June 1976 
to May 1977) at four to seven weeks intervals. Each day samples were collected at $06: 00,12: 00,18: 00$ and 24:00, in three levels: surface, $2 \mathrm{~m}$, and near the bottom ( 3.5 to $4.5 \mathrm{~m}$ according to tide).

Each station lasted one hour. From each leve1, Nansen bcttle water samples for dissolved oxygen and salinity analysis were taken, and $99 \ell$ of water (sampled with a $9 \ell$ van Dorn bottle) were filtered throughout a $37 \mathrm{micramesh}$ size net and praserved in neutral formalin $4 \%$. Bottom

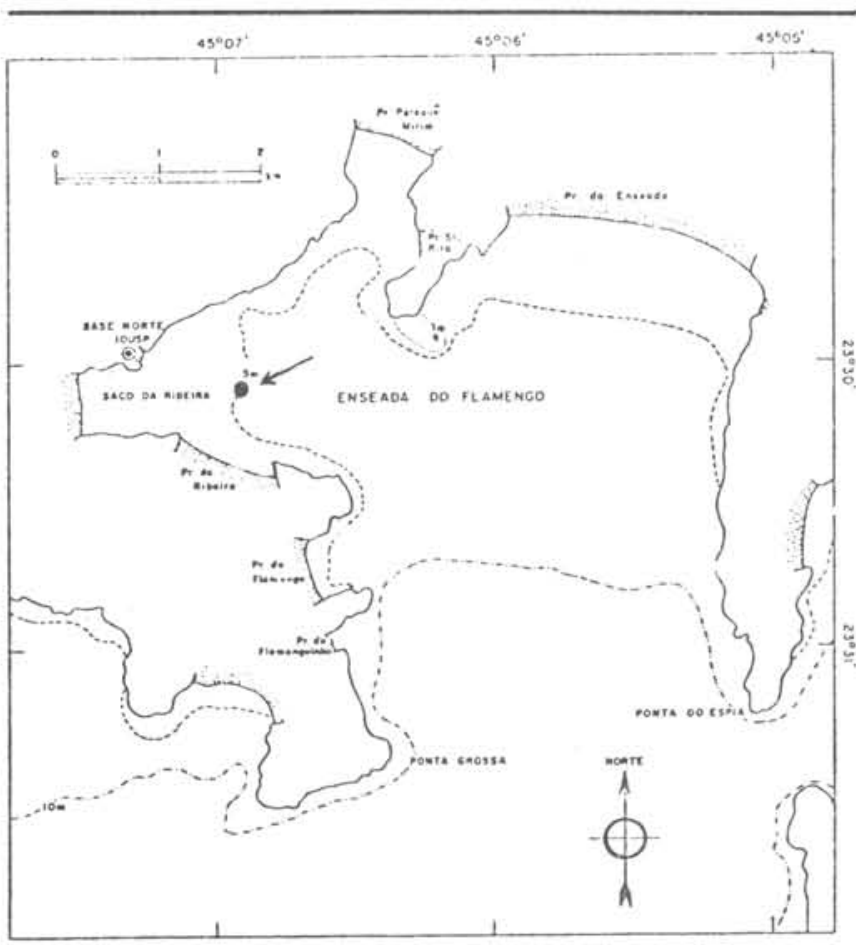

Fig. 1. Sampling station.

and surface net plankton samples were also collected, but were not analysed. Environmental fastors were recorded: light penetration, temperature (with a reversing termometer fitted to the Nansen bottle), solar radiation, and tide records.

Dissolved oxygen was titrated by Winkler's method and salinity was measured by conductivity. Al1 individuals of $P$. crassirostris in the bottle samples were counted, separately each stage.

Identification of nauplia was based on Björnberg's (1972) paper, and that of copepodids on Lawson \& Grice's (1973).

\section{Environment}

Enseada do Flamengo is a sheltered bay, surrounded by high lands and islands, without important fresh water affluents. Semidiurnal tides are the principal mixing mechanism with adjacent water masses (Teixeira, 1973). Waters are eumixo- haline with temperatures between 20 and $30^{\circ} \mathrm{C}$.

The,e are two seasons, not sharply separated. In winter the inflow of fresh water due to rain are greater than in summer, and consequently the salinities recorded were lower; the water column in this period was mixed, without strong dissolved oxygen and temperature gradients. In summer bigger differences were found between surface and bottom records of salinity, dissolved oxygen and temperature (Figs 2, 3, 4). In the s-me area, similar results were found by Teixeira

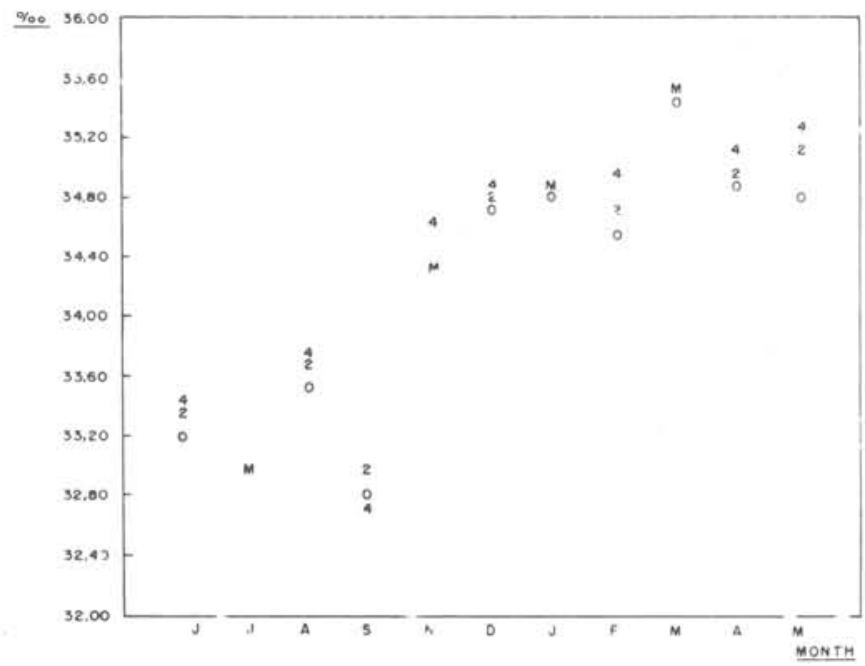

Fig. 2. Salinities at 0.2 and $4 \mathrm{~m}$, throughout the year. Data of the four sampling hours joined. M: superposition of values of two or three depths.

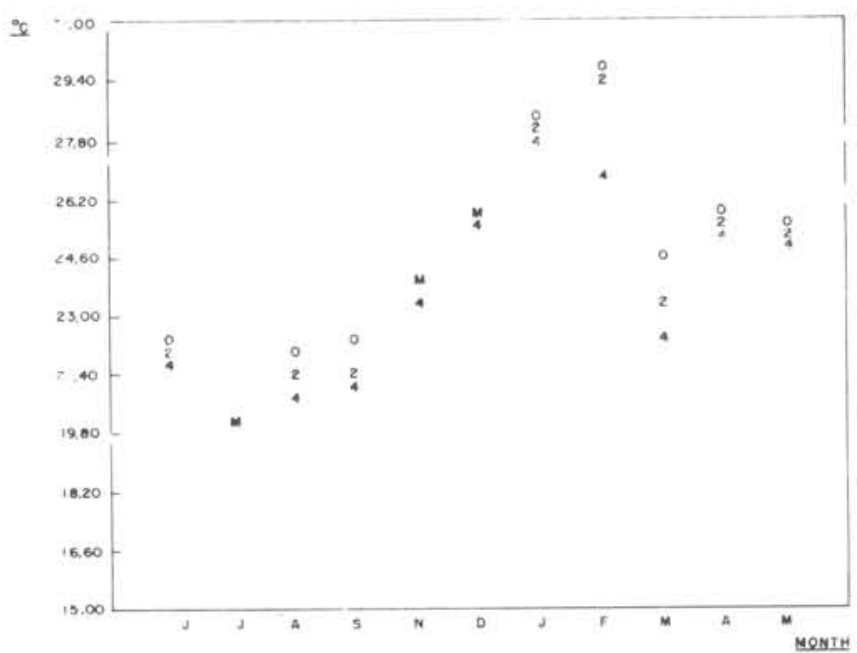

Fig, 3. Temperature at 0.2 and $4 \mathrm{~m}$, throughout the year. Data of the four sampling hours joined. M: superposition of values of two or three depths. 


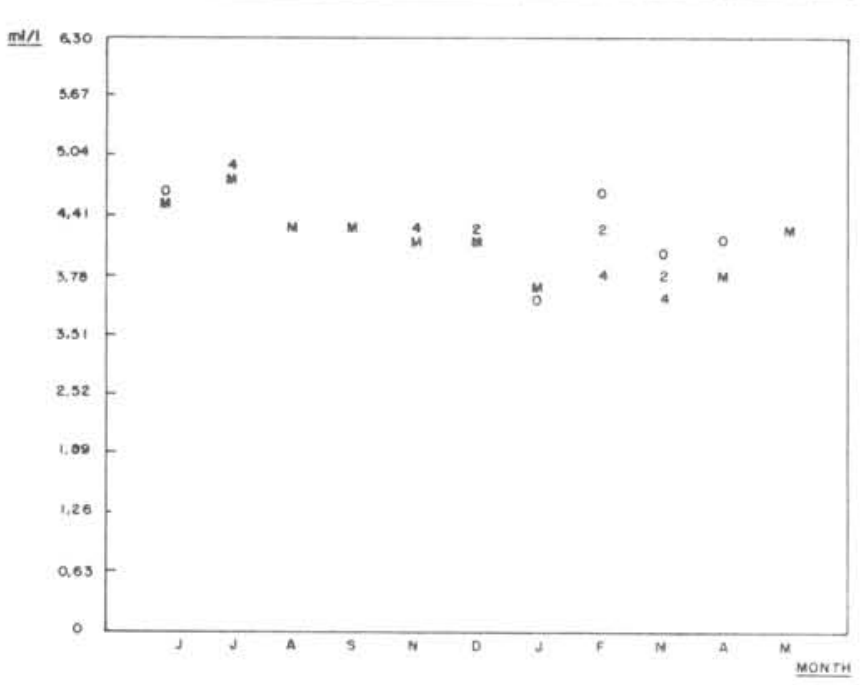

Fig. 4. Dissolved oxygen at 0.2 and $4 \mathrm{~m}$, throughout the year. Data of the four sampling hours joined. M: superposition of values of two or three depths.

(1973), who also studied other physical and chemical factors, and by Nonato, Miranda \& Signorini (1974, according to Amaral, 1977). Other detailed descriptions of the area are given by Schaeffer-Novel1i (1976), Amaral (1977), Fernandez (1977) and Pires (1977).

Statistical analysis

The use of the general linear model (Omega) in biology was discussed by Seal (1966) and utilized in marine biology by Buzas (1969, 1971); computacional procedures can be found in BMD Manuals (Dixon, 1974) as "General Linear Hypothesis". The data were computed in the Burroughs B-6700 System of the Centro de Computação Eletrônica da Universidade de São Paulo.

The least squares technique known as regression analysis of a linearmodel was used. This method seeks to "explain" a single variate in terms of a number of other variables (independent variables and covariables).

If the residuals are assumed to have been independently sampled from one normal distribution, their own distribution can be assumed to be normal with zero mean $\left(\mathrm{N}\left(0, \sigma^{2}\right)\right)$, and the "best" numerical values of the parameters of the model will be obtained by minimizing the sum of squares of the residuals respect to variation in these parameters (Seal 1966, p. 7).

To be sure that the distributions were normal, standard deviation against mean was plotted for each stage of $P$. crassirostris; each point of the graphics rises from the data of one month. In all figures these parameters turn out to be linearly proporcional, so that the appropriate transformation for normalizing the data and stabilizing the variance is the logarithmic one (Barnes, 1952). To avoid the problem of samples with no individuals, $\log (n+1)$ was used.

The independent variables values of the factorial design (hour and depth) were fixed a priori, and can be considered free of error.

Model Omega was constructed a priori, taking into account animal densities, environmental variables, depth differences, hour differences, and the interaction of depth and hour differences. In order to know which parameters are significantly different from zero, model Omega was compared with several more restricted omega models. Each of these restricted mode1s were obtained equating a group of parameters of the general Omega model to zero.

A significant effect of a factor means that this factor accounts for at least part of the variation of the number of animals found in the samples, at the significance level considered.

In matrix notation model Omega can be written as

$$
\begin{aligned}
& x_{i j k}=Z^{\prime} \cdot \beta+e_{i j k} \\
& (N \cdot 1) \quad(N \cdot q)(q .1) \quad(N \cdot 1)
\end{aligned}
$$

where $x$ is the vector of $N$ observations, $i=1,2,3,4$ hours, $j=1,2,3$ depths, $k=1,2$ replicates (months), $Z^{\prime}$ is a matrix of instrumental variables and covariables, $\beta$ is a vector of $q$ parameters to "explain" the $N$ observations, and $e$ is a vector of "errors" or "residuals" not accounted for by the model and assumed to be $\mathrm{N}\left(0, \sigma^{2}\right)$.

Matrix Z' rises from equations on Table I.

The makeup of the columns of matrix $Z^{\prime}$ is shown in Table II. Each element of vector $z_{0}$ is 1 , so that, by making each of the other vectors of instrumental variables sum to zero, $\beta_{0}$ becomes the mean of all observations. Vectors $z_{1}$ through $z_{3}$ account for hour differences (line effect in factorial design), vectors $\mathrm{z}_{4}$ and $\mathrm{z}_{5}$ account for depth differences (column effect); interaction vectors $z_{6}$ through $z_{11}$ were obtained by multiplying hour differences vectors by depth differences vectors; 
Table I - Equations of Model OMEGA

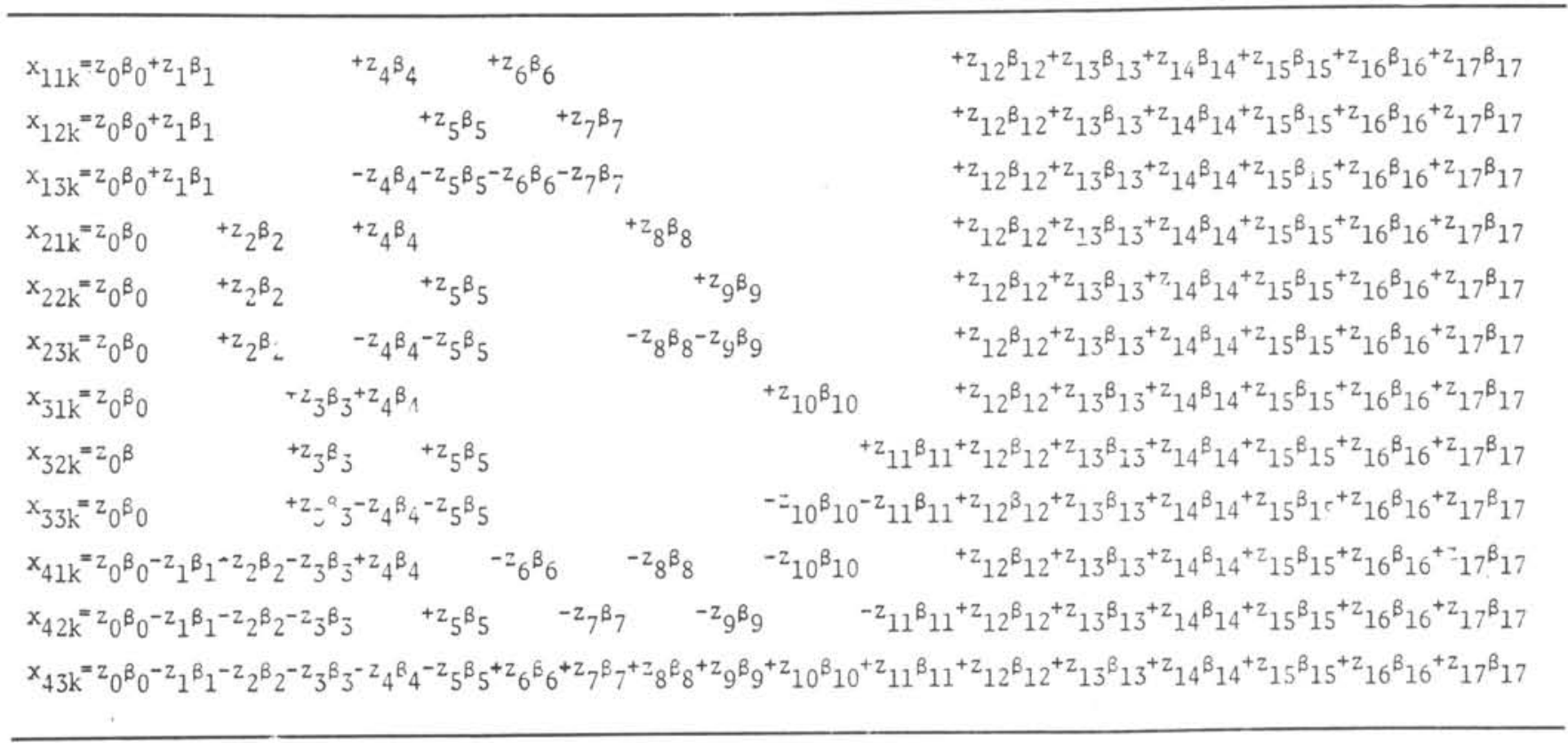

Table II - Vectors of $Z^{\prime}$ matrix

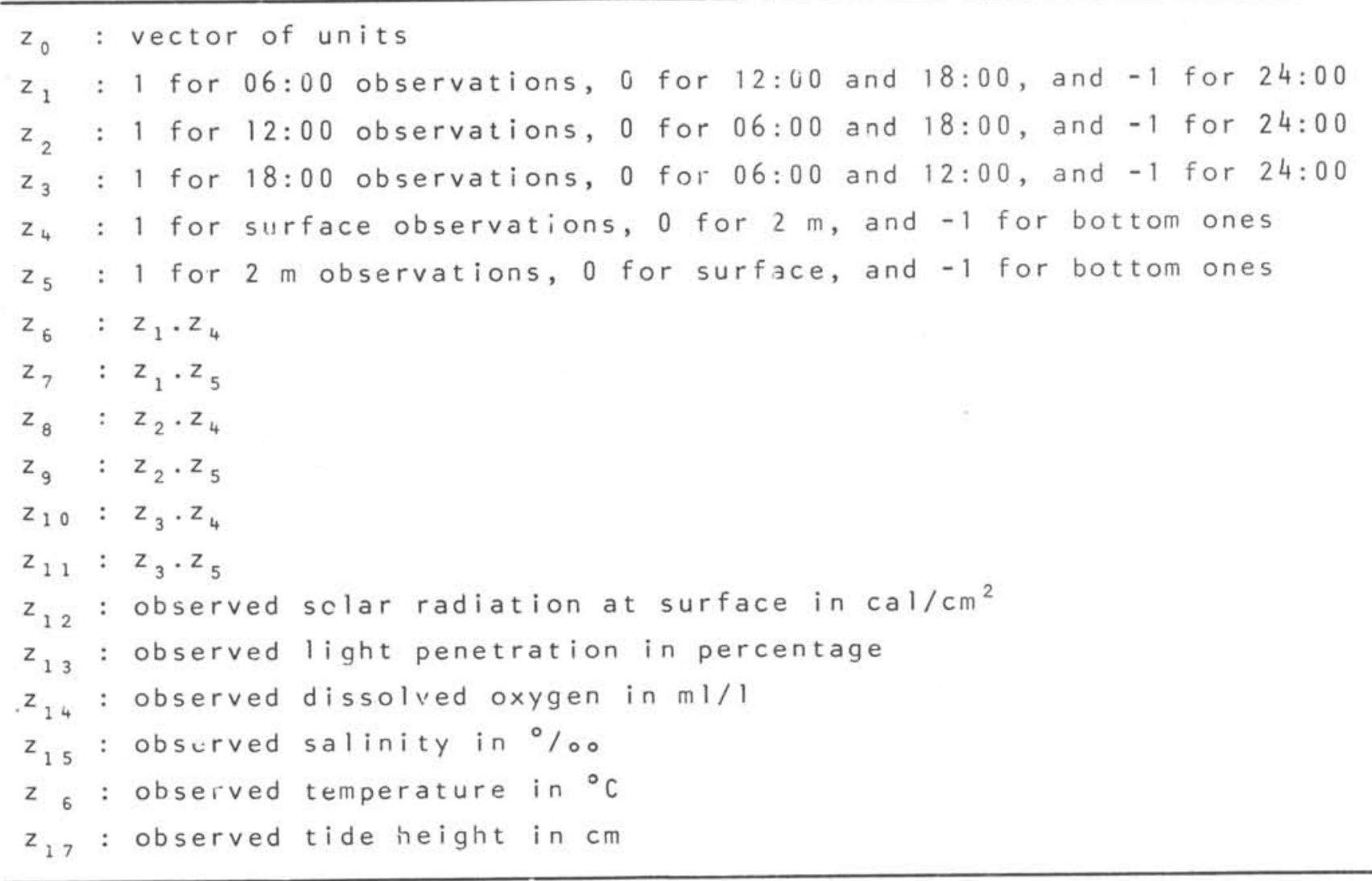

vectors $z_{12}$ through $z_{17}$ are the observed values of solar radiation, light penetration, dissolved oxygen, salinity, temperature and tidal records respective$1 \mathrm{y}$.

The sum of squares of residuals $\left(\mathrm{S}_{\Omega}\right)$ are obtained after estimating not only the mean but also other 15 or 17 parame- ters.

The estimate of the variance which governs the distribution of the residuals in the Omega model is

$$
\sigma^{2}=\frac{s_{\Omega}}{N-q}
$$


and $\mathrm{S}_{\Omega} / \sigma^{2}$ is distributed as $X^{2}$ with $\mathrm{N}-q$ degrees of freedom (Seal 1966, p. 13).

The restricted omega models can be written as

$$
\begin{aligned}
& x_{i j k}=z^{\prime} \cdot \beta_{(N .1)}+e_{i j k} \\
& (N . S)(s .1)(N .1)
\end{aligned}
$$

where in each model $q-s$ parameters of the Omega model are supressed. The adequacy of each restricted Omega model is proved comparing it with the omega model by means of the ratio

$$
F_{q-s, N-q}=\frac{\left(s_{\omega}-s_{\Omega}\right) /(q-s)}{s_{\Omega} /(N-q)}
$$

Four restricted models were tested: 1 -hour effect; 2-depth effect; 3 interaction effect; 4 -overall environmental effect (Table III).

Table III-Restricted (omega) models

\begin{tabular}{lll}
\hline \multicolumn{3}{c}{ Hypothesis } \\
w $\quad B_{i}{ }_{i}=0$ & Effect \\
1 & $i=1,2,3$ & hour \\
2 & $i=4,5$ & depth \\
3 & $i=6, \ldots, 11$ & depth-hour interaction \\
4 & $i=12, \ldots, 17$ & environmental variables \\
\hline
\end{tabular}

Environmental variables are not independent and cannot be arbitrarily equated to zero, either single or in groups. In this case, Sheffé's S method was used (Seal 1966). It gives the confidence limits of each parameter of a group which, as a whole, is significantly different from zero. If the intervals overlaps zero it can be said, with the probability considered, that that parameter does not account for the significance of the group.

Due to planktonic system characteristics, when a phenomenon is studied, it is expected to find both, strong variations in little time and space scales and long term tendencies. In the particular case of this study space was fixed, and the expected time variations are differences of the vertical distribution pattern during one day in the different months; a previous study of this type, based on part of the material used in this paper, has already been done (Milstein, in press). More general tendencies could be studied joining the data of each season or of all the year. In this paper an intermediate approach was chosen, which eliminates part of that variation and shows the tendencies in relative short periods: 2 months. In the repetition of the process using several groups of two months can be examined the variation of that tendency throughout the year. The process was reiterated nine times for each stage of $P$. crassirostris, with the following groups of months: June-July (JJ), July-August (JA), AugustSeptember (AS), November-December (ND), December-January (DJ), January-February (JF), February-March (FM), March-April (MA), and April-May (AM). Within each group envi ronmental conditions were alike. There was a gap of seven weeks between September and November stations, and general conditions (especially salinity) were so different that the analysis of the group was neglected.

\section{Possible error sources}

There are relatively few zooplankton works in which sample bottle were used. Hodgkiss (1977) made simul taneous collections with Nakai nets and $1 \ell$ Friedinger bottle, finding good correlation between them in relation to seasonal patterns of planktonic population distributions, but little significant correlations appeared in the study of vertical distributions and relative abundance of each species. Working with $2 l$ van Dorn bottles, Stickney \& Knowles (1975) found that Pseudodiaptomus coronatus, Neomysis americana, adul ts of Acartia tonsa and other copepods of similar size, were negatively selected; at the same time, Euterpina acutifrons and other small organisms were suitably represented in the samples. Tundisi (1972), in spite of working with a bigger sample bottle ( $8 \ell$ modified PettersonNansen) also found that the adults of the bigger species were negatively selected (Acartia lilljeborgi, Pseudodiaptomus acutus, Labidocera fluviatilis) and the smaller copepods adequately sampled ( $P$. crassirostris, Oithona ovalis, Euterpina acutifrons). In the present paper subsamples of three surface net samples were counted and compared with the respective bottle samples (Table IV); adults and bigger copepodids percentages were similar in both copies. On the other hand, nauplia were underrepresented in bottle samples, probably due to filtration through the 37 micra mesh 


\begin{tabular}{|c|c|c|c|c|c|c|}
\hline \multirow[b]{2}{*}{ Females } & \multicolumn{2}{|c|}{$\begin{array}{l}\text { June, } 06: 00 \\
\text { net bottle }\end{array}$} & \multicolumn{2}{|c|}{$\begin{array}{c}\text { March, } 12: 00 \\
\text { net bottle }\end{array}$} & \multicolumn{2}{|c|}{$\begin{array}{l}\text { March, } 24: 00 \\
\text { net botile }\end{array}$} \\
\hline & 42.9 & 46.1 & 42.6 & 33.3 & 65.9 & 66.6 \\
\hline Males & 40.3 & 44.7 & 22.3 & 15.9 & 17.3 & 17.3 \\
\hline c. $v$ males & 4.6 & 0.6 & 11.0 & 12.0 & 7.6 & 6.4 \\
\hline c.v females & 5.3 & 5.3 & 11.5 & 17.7 & 5.1 & 4.7 \\
\hline c. IV & 6.8 & 3.4 & 12.7 & 21.1 & 4.0 & 5.0 \\
\hline
\end{tabular}

size net; they were still less represented in samples of surface net ( 75 micra mesh size).

Paracalanus quasimodo, which is bigger than $P$. crassirostris but very similar to it, has been frequently found in the samples. The nauplia of the two species can be told one from the other only by their size and the diameter of metasome. In some samples appeared Paracalanus nauplia I and II, which still have no metasome developed; they were not counted because it was not possible to know to which of the two species they belonged.

Nauplia III to VI were counted separately, but were considered as a group in the statistical analysis, because there were many samples with few of these organisms .

The following requirements of least squares technique are fulfilled (Hoffmann \& Vieira, 1977): a-fixed values of independent variables chosen a priori; b-independent variables free of error; the small variations in depth of sample bottle or in the hour of beginning and end of sampling station that could happen can be disregarded and the two variables considered free of error; $c$-due to the left skewed frequency distribution of the numbers of animals in the samples the logarithmic transformation used aims to make it more normal; because of this more normal distribution the distribution of the residuals are assumed to be $N\left(0, \sigma^{2}\right)$; $\mathrm{d}$ - the logarithmic transformation also stabilizes the variance, and it was assumed that the residuals were homocedastic.

Nauplia analysis of JJ was not performed due to the accidental lost of all of them of the surface 24:00 hours sample.

Four to six covariables were considered in each analysis, due to lack of light penetration percentages in Sep- tember, solar radiation data in February and March, and tidal records in December, April and May.

\section{Results}

$X^{2}$ tests of goodness of fit of the 89 Omega models were computed (Table V). It was also made a $X^{2}$ test of those 89 $X^{2}$, which showed that the fit was suitable (1.209 for $3 \mathrm{df})$ at 0.05 significance level. The non significant 0.05 $X^{2}$ shown in Table $V$ are due to random variability; they are those expected to

Table $V-X^{2}$ values of the 89 OMEGA models. **: 0.01 significance level; df: degrees of freedom

\begin{tabular}{|c|c|c|c|c|c|c|}
\hline & $d f$ & Gemales & males & C. $V$ males & c. v fem. & C.IV \\
\hline J J & 6 & $0.22 \star \star *$ & $0.19 * *$ & $0.59 \star \star$ & $0.09 * *$ & $0.16 \star *$ \\
\hline$J A$ & 6 & $0.22 \star \star$ & $0.84 \star \star \pi$ & $0.63 * \star$ & $0.14 k \star$ & $1.13 *$ \\
\hline AS & 7 & $0.36^{\star \star}$ & $0.83^{\star \star}$ & $0.81^{\star \star}$ & $0.44 * *$ & $0.66^{\star \star}$ \\
\hline ND & 7 & $0.06^{\star \star}$ & $0.21^{\star *}$ & $1.96^{\star}$ & $0.50^{* \star}$ & $0.79^{\star \star}$ \\
\hline DJ & 7 & $0.12^{\star \star}$ & $0.59^{\star \star}$ & $1.41^{\star}$ & $1.13^{\star \star}$ & $0.96^{\star \star}$ \\
\hline JF & 7 & $0.47^{\star \star}$ & $1.53^{\star}$ & $0.53^{\star \star}$ & $0.81^{\star \star}$ & $0.47^{\star \star}$ \\
\hline$F M$ & 7 & $1.23 \star$ & $1.05 * \star$ & $1.51 *$ & $1.62 *$ & 2.29 \\
\hline MA & 8 & $0.47^{* *}$ & $1.03 \star \star$ & $1.33^{\star \star}$ & $2.08 *$ & $2.08 *$ \\
\hline \multirow[t]{2}{*}{$A M$} & 7 & $0.82^{\star *}$ & 4.51 & 4.06 & 3.25 & 2.88 \\
\hline & & C.111 & C.II & C. 1 & Copepod. & Nauplia \\
\hline JJ & 6 & $0.46 \pi *$ & $1.02 *$ & 1.83 & $0.17^{\star \star}$ & \\
\hline JA & 6 & $0.97^{\star}$ & $0.62^{\star \star}$ & $0.69^{\star \star}$ & $0.08 * \star$ & $0.60 * *$ \\
\hline AS & 7 & $0.23^{\star \star}$ & $0.65^{\star \star}$ & $0.69^{\star \star}$ & $0.005^{\star \star}$ & c. $64 * *$ \\
\hline NO & 7 & $1.11^{\star \star}$ & $1.22^{\star \star}$ & $0.93^{\star \star}$ & $0.039 * \star$ & $0.66^{* \star}$ \\
\hline DJ & 7 & $2.08^{\star}$ & $0.70^{\star \star}$ & $0.28 * \star$ & $0.032 \star \star$ & $0.82^{\star \star}$ \\
\hline$J F$ & 7 & $1.39^{\star}$ & $0.25^{\star \star}$ & $0.28^{\star \star}$ & $0.031 * \star$ & $0.49^{\star \star}$ \\
\hline FM & 7 & $2.00 *$ & $0.93^{\star \star}$ & $0.62^{\star *}$ & $0.002^{\star \star}$ & $0.79^{\star \star}$ \\
\hline MA & 8 & 3.58 & 2.38 * & $1.52^{\star \star}$ & $0.02^{\star \star}$ & $0.75^{\star \star}$ \\
\hline AM & 7 & 3.73 & 3.87 & 2.44 & $0.004 * \star$ & $0.37^{\star \star}$ \\
\hline
\end{tabular}

happen with a probability of $5 \%$ if the Omega models show goodness of fit with a probability of $95 \%$. The fact that most of these no significant records occurred in AM has probably some relation to a phytoplankton bloom which took place in May; only few zooplankters were present in May's samples.

As an example, it was chosen one omega model to plot observed and expected values. Figures 5, 6 and 7 show, for each depth, observed mean (0) of June and July females $\log (n+1)$ numbers at the four sampling hours, and the expected values (E) predicted by the Omega model corresponding to those months.

Results of comparisons between each restricted (Omega) mode1 to the general (omega) model are shown in Table VI, 


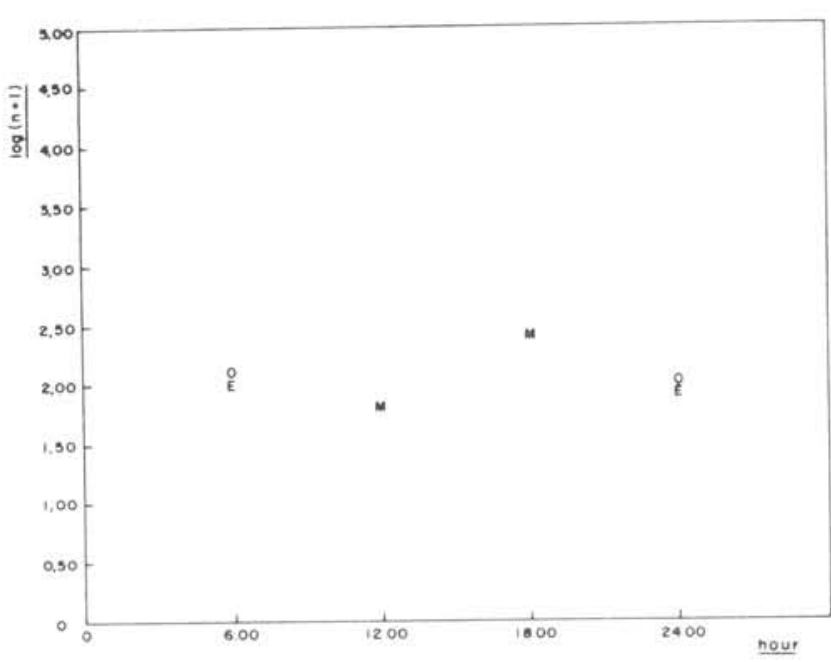

Fig. 5. Observed ( 0 ) and expected (E) females log numbers at surface at each sampling hour, for June-July. M: superposition of observed and expected values.

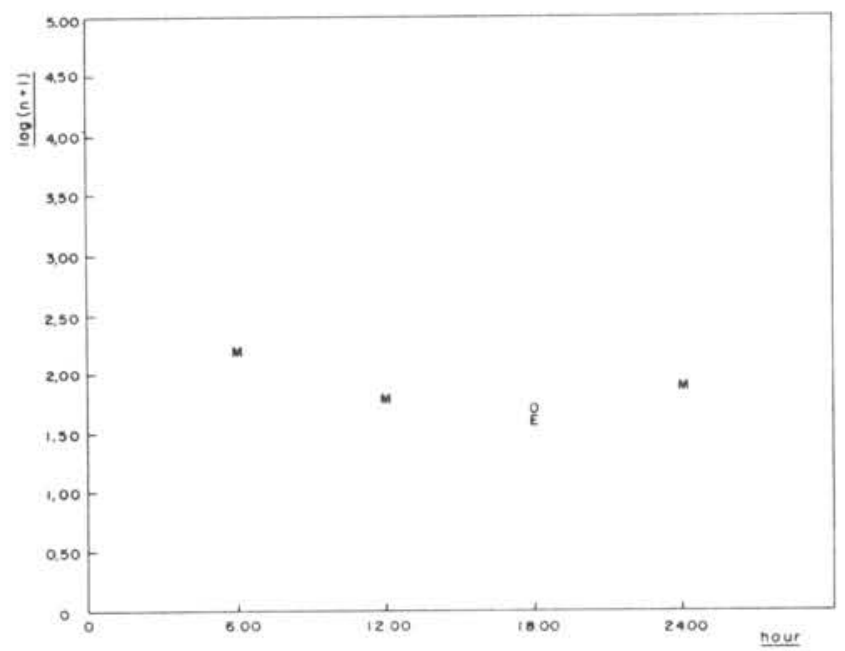

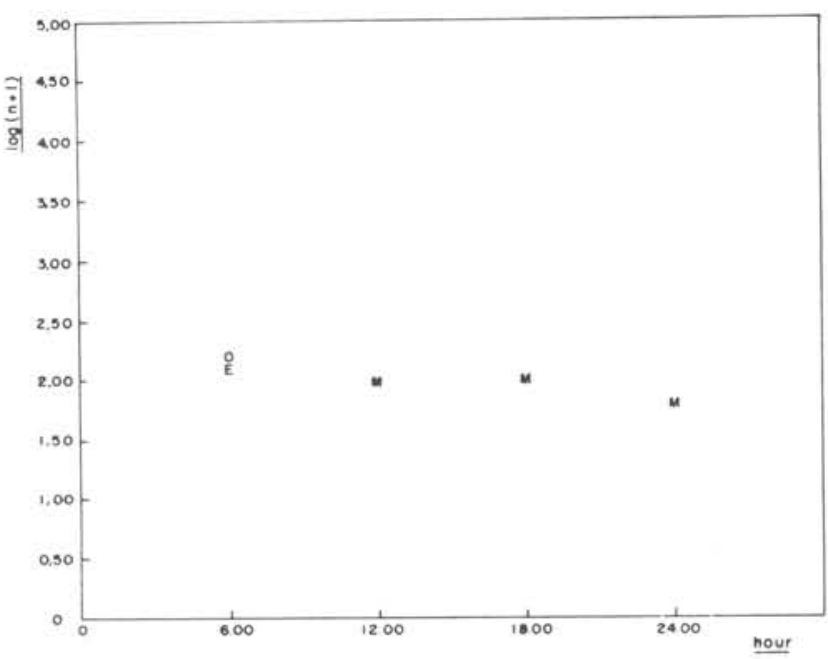

Fig. 6. Observed ( 0 ) and expected (E) females $\log$ numbers at $2 \mathrm{~m}$ at each sampling hour, for JuneJuly. M: superposition of observed and expected values.

Fig. 7. Observed ( $O$ ) and expected (E) females log numbers on the bottom at each sampling hour, for June-July. M: superposition of observed and expected values. separately for each developmental stage ( 0.05 and 0.01 significance levels).

At first glance at Table VI, it can be seen that the amount of $P$. crass $i-$ rostris of any developmental stage is diversely affected by the different factors throughout the year, and that these effects are stronger in summer.

The hour was not always significant for any developmental stage. Most significances occurred in ND, in adults, C. V female, copepodids (as a group) and nauplia. Nauplia and C. I also showed significance in other summer months-groups, and C. III, C. IV, C. V females, copepodids joined and males in winter. The hour at which the greatest abundance was recorded was generally the same in the same couple of months for all developmental stages, and different in different couples of months.
This suggests that the amount of organisms at a given hour depends more on the currents (tides) than on animals behaviour in relation to hour.

Depth was significant only for C. I, C. II and nauplia in JF, which in that moment were on the bottom. This suggests that animals are generally spread in the water column.

Depth-hour interactions showed significance also in few occasions, pointing out that none of the developmental stages of $P$. crassirostris performs regular vertical migration.

Overall environmental effects were significant many times in all stages (except in copepodids grouped), especially in summer; in winter they were not significant for C. I, C. II and C. III. It was not possible to analyse each environmental factor alone. The confi- 
Table VI - Results of the comparisons between the restricted models and the OMEGA model. **: 0.01 significance level; *: 0.05 significance level

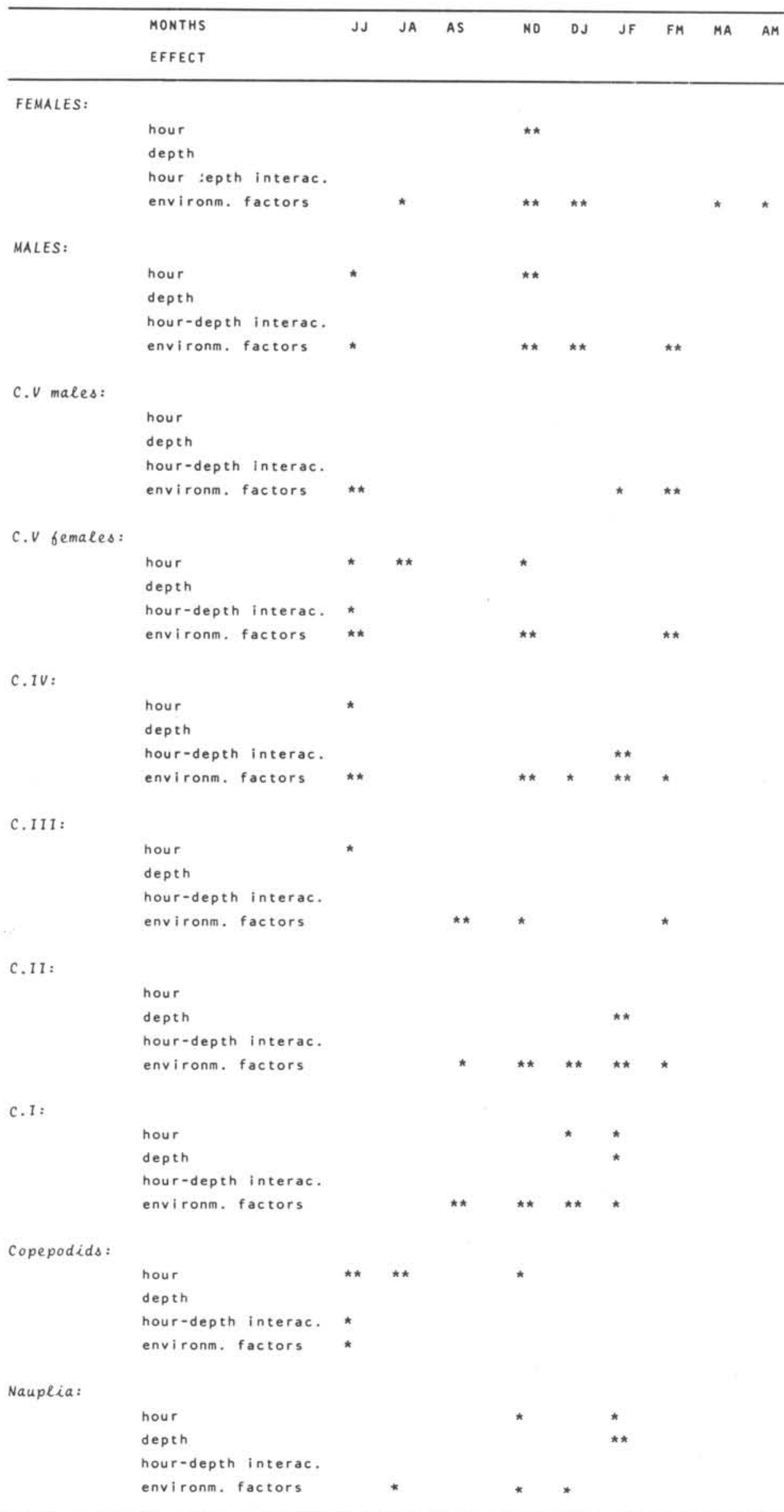


dence limits found through Sheffé's method for the parameters which measure their effect were absurdly wide, due to the smal1 number of observations (24) in each analysis (Seal 1966, p. 62).

\section{Discussion}

Zooplankton vertical migration are traditionally studied plotting amount or percentage of animals as a function of depth and hour of sampling. In both cases, interpretation is easy when there are many organisms and vertical distribution pattern changes clearly with time.

Percentages can lead to wrong conclusions, especially when few zooplankters are present.

Several authors made use of more objective methods. Moore (1953) developed a method to study the vertical distribution of species in relation to the depth in which a certain percentage of the population is found, and not to the absolute depth; this method was improved and completed through the study of variations throughout the day of physical factors effects on animal's distribution (Moore et all, 1953; Moore, 1955; Moore \& Corwin, 1956; Moore \& O'Berry, 1957; Moore \& Bauer, 1960). Vinogradov (1970) developed another method to measure vertical migration intensity; these two methods need continuously sampled water layers (net samples). Angel \& Fasham (1973) introduced factor analysis in the study of vertical migration as a way of grouping species of similar vertical migration behaviour; this analysis was used later by Angel \& Fasham (1974) and Marlowe \& Miller (1975). The analysis of variance was used in the study of daynight plankton sample variability (Glover \& Pope, 1956; Sameoto, 1975), and in the study of vertical migration proper (Pearcy et all, 1977).

In the present paper the statistical method utilized includs an analysis of variance, with the advantage that the sums of squares of residuals are obtained estimating not only the mean, but other 15 or 17 parameters as we11, and that the multiple regression on the environmental variables are computed in the same model; this is the first time that this model is fitted to this kind of data.

Differences in vertical migration behaviour of different developmental stages and sexes of holoplankters have been pointed out in classical papers Russe1, 1927; Cushing, 1951) and in modern reviews (Banse, 1964; Vinogradov, 1970; Longhurst, 1976). In spite of that, most of vertical migration researchers still work at the species level and do not state clearly which stages were studied. Bradford (1970) draws attention on this problem, and studies separately the vertical migration of males and females of each species in her material.

In shallow waters there were found both, copepods which do present different vertical migration behaviour in their different stages and copepods which do not show these differences. In samples collected at short intervals throughout one day, Furuhashi (1976) found a greater difference between day and night numbers of Acartia clausi males at surface than of females, and some little differences between both sexes of Paracalanus $\mathrm{sp}$ and oithona nana. Working with material collected with the same kind of sample program, Grindley (1977) found that peaks of abundance of several developmental stages of Acartia longipatella occurred at the same hour but the percentage of migrating adults were greater than that of copepodids; no difference was found in Pseudodiaptomus hessei; the author does not give data separately for each stage of $P$. crassirostris. Björnberg \& Wilbur (1968) contrasted the vertical migration of adult Acartia lilljeborgi and the 1 ack of this phenomenon in their copepodids. Conover (1956) marked the same fact for $A$. clausi and A. tonsa.

Differences in $P$. crassirostris males and females behaviour were already pointed out in a previous paper (Milstein, in press) based on noon and midnight samples of the same material studied here. In that paper was stated that both sexes were spread in the water column but that males showed a weak tendency to concentrate near the bottom, especially at noon; correlation coefficients of numbers of males (or their logarithms) to depth were low (less than $0.35)$; correlation coefficients of females to depth were not significant. In the present new approach of the data, non significant differences in the amount of males at a given depth were found throughout the year, and the differences due to sampling hour were not steady. The discrepancies between these results are due to the methods used: in the first case simple correlation coefficients of one year noon and midnight samples were calculated, and in the 
Bolm Inst. oceanogr., S Paulo, 28(2), 1979

second case the results rose from an analysis of variance of four hours data of eleven two-month groups. The computation of all the data of all the year by means of the Omega model could confirm or nullify the weak tendencies found through the simple correlation analysis.

Björnberg \& Wilbur (1968) studied P. crassirostris' vertical migration in the laboratory; animals were generally spread in the water column, showing a weak vertical migration cycle: they concentrate in the surface at night and on the bottom during lighthours. Grindley (1977), working with samples collected at short intervals throughout one day, noticed that $P$. crassirostris was present at surface all the day, but in greater numbers during darkhours.

In the first work on Ubatuba's material (Milstein, op.it) it was found that when these animals showed vertical migration they were very weak and of the inverted type in summer (during daylight in the surface layer and at night on the bottom). In the present paper a probabilistic model was used, which is generally more objective and reliable than a graphical analysis, especially when the graphics only show tendencies and not clear behaviours; besides, the $10 \mathrm{~g}$ transformation used tends to minimize weak behaviours. These two considerations explain the discrepances between the results of the present paper and those of the already mentioned articles by Björnberg \& Wilbur, Grindley and Milstein; the differences in the amount of animals collected in the various depth-hour combinations are those expected to be found with $95 \%$ probability if these organisms do not migrate strongly. Clear migrations became evident only three times in 89 analysis, which suggests the lack of a clearly developped migratory behaviour in all the developmental stages of $P$. crassirostris throughout the year.

The influence of environmental factors on vertical distribution of $P$. Crass $i-$ rostris became evident in most analysis of the present paper. It was not possible to study each factor alone. In the previous paper (Milstein,op. cit.) simple correlation coefficients between numbers of adults (absolute and 1 og numbers) and salinity, temperature and dissolved oxygen were calculated, and tidal effect on the variation of $P$. crassirostris abundance was discussed. Females proved to be more euroic than males, showing only low correlation to temperature; males showed correlation to salinity only at midnight, and stronger correlation to temperature at noon and at midnight; no correlation to dissolved oxygen was found. Lance (1964) studied salinity tolerance of several estuarine crustaceans, and found that females were more tolerant than males and copepodids. It is evident the significance of environmental factors on zooplankton distribution, and the different responses of females, males and young forms to them; these factors proved to be more important for $P$. crassirostris than depth and hour.

In connection to tides, in the previous paper (Milstein, op.cit) more organisms were recorded at high tide. Jacobs (1968) and Pillai \& Pillai (1973) also found more animals at high tide, and a combination of tidal and vertical migration effects on the distribution of organisms. Grindley (1977) also found a superposition of tidal effect and vertical migration: at night the numbers of $P$. crassirostris and other plankters were lower at low tide than the rest of the night; during the day there was no difference between their numbers at low and high tides. Sameoto (1975) found tidal correlation to numbers of several nonmigrating copepods; migrating animals did not show tidal correlation. In a general way it could be said that, in shallow waters, animal concentration are greater at flood than at ebb, and that this effect is strongerinorganisms that show weak vertical migration than in plankters that can partially "escape" to it through their migratory behaviour. $P$. crassirostris belongs to the first group; in the present paper it seems that hour was significant due more to tidal effect than to itself, because those significant points appeared only few times for each stage and almost always in the same groups of months for several stages ( $\mathrm{JJ}$ and $\mathrm{ND}$ ).

Björnberg \& Wilbur (op.cit) related vertical migration of copepcds to feeding behaviour: strong vertical migration in predators and weak ones in fine particle grazers; in shallow waters there are fine particles suspended at all depths, and grazers of these particles showed weak vertical migration ( $P$. crassirostris and Acartia lilljebargi copepodids); zooplankton accumulates on the bottom during daylight in shallow wnters, and predators (Calanopia americana) showed stronger vertical migration than omnivorous forms (adult A. lilljeborgi). This agrees with Sameoto (1975), who computed 
correlation coefficier's among a11 planktonic species in his samples, and could tell a vertical migrating community of predators from a nonmigrating community of preys consisting of copepods. The results of the present paper support these ideas, showing the 1 ack of vertical migration in all stages of a coastal water copepod which is a fine particle grazer during all its life.

As it was pointed out in the statistical analysis section this linear model can be fitted to the data of several clustered months in order to study more general tendencies; that study, based on the same data of this paper, will be developed in future research.

\section{Acknowledgements}

I would like to thank Dra. Maria Scintila de Almeida Prado for her help and guidance throughout this study, and to the "Instituto Oceanográfico da Universidade de São Paulo" for allowing me the use of the facilities of the Department of Biological Oceanography and of the coastal station at Ubatuba.

\section{Resumo}

A distribuição vertical dos diferentes estádios de desenvolvimento de $P$. crassirostris foi estudada durante um ano (junho 1976 - maio 1977), numa estação pouco profunda $(5 \mathrm{~m})$ em Ubatuba. As amostras foram coletadas mensalmente, em três profundidades, cada quatro horas, com garrafa van Dorn de $9 \ell$, registrando-se dados ambientais.

Os dados foram processados com a técnica dos Mínimos Quadrados, na forma de uma Arálise de Regressão de um Modelo Linear que inclui covariáveis. 0 modelo foi construído a priori, considerando densidade de organismos por amostra, fatores ambientais, diferenças entre amostras procedertes de diferentes profundidades e horas, também como interações entre hora e profundidade. Para cada estádio de $P$. crassiros ris, o modelo foi repetido 9 vezes, com os dados de dois meses cada vez, a fim de obter a variação das respostas no ano.

Os resultados do modelo indicaram que a quantidade de indivíduos desta espécie de qualq er estádio é diferentemente afetada durante o ano pela hora, profundidade, interação hora-profundidade, e fatores ambientais. Esses efeitos seriam mais marcados no veräo. A maior ou menor ocorrência de organismos numa dada hora parece depender mais da dinâmica do sistema de correntes (marés) que do comportamento dos animais. Todos os estádios apresentaram-se distribuídos na coluna de água e não mostraram migrações verticais marcadas como parte do seu comportamento normal. Os fatores ambientais em conjunto mostraram-se importantes na distribuição deste organismo, especialmente no verão.

Björnberg \& Wilbur (1968) e Sameoto (1975) relacionaram o comportamento migrador pouco marcado ou ausente com o nivel trófico que os planctontes costeiros ocupan. Os primeiros autores assinalaran a presença de partículas finas em todas as profundidades em águas rasas, e a migração pouco definida de copépodos filtradores provenientes desse tipo de $\bar{a}-$ gua; o segundo autor distinguiu, em águas pouco p? ’fundas também, uma comunidade formada por predadores e uma comunidade de piesas formada por copépodos não migradores. Os resultados do presente trabalho apóiam essas idéias, mostrando a falta de migração em todos os estádios de um copépodo que é, durante toda a sua vida, filtrador de partículas finas.

\section{Bibliography}

AMARAL, A. C. Z. 1977. Anelídeos poliquetos do infralitoral em duas enseadas da região de Ubatuba: aspectos ecológicos. Tese de Doutorado. Universidade de São Paulo, Instituto Oceanográfico, $140 \mathrm{p}$.

ANGEL, M. V. \& FASHAM, M. J. R. 1973. SOND cruise, 1965: factor and cluster analyses of the plankton results, a general summary. J. mar. biol. Ass. U. K., 53:189-231.

SOND cruise, 1965: further factor analyses of the plankton data. J. mar. biol. Ass. U. K., 54:879-894.

ANRAKU, M. 1964. Influence of the Cape Cod Canal on the hydrography and on the copepods in Buzzards Bay and Cape Cod Bay, Massachusetts. I. Hydrography and distribution of copepods. Limnol. Oceanogr., 9(1):46-60.

BANSE, K. 1964. On the vertica1 distribution of zooplankton in the sea. Progr. Oceanogr., 2:53-125.

BARNES, H. 1952. The use of transfornitions in marine biological sta- 
tistics. J. Cons . perm. int. Explor. Mer, 18:61-71.

BJÖRNBERG, T. K. S. 1963. On the marine free-living copepods off Brazil. Bolm Inst. oceanogr., S Paulo, 13(1): 3-142.

1972. Developmenta1 stages of some tropical and subtropical planktonic marine copepods. Stud. Fauna Curaçao, 40 (136) :1-185.

\section{\& WILBUR, K. M.}

1968. Copepod phototaxis and vertical migration influenced by Xanthene dyes. Biol. Bul1. mar. biol. Lab. Woods Hole, 134 (3) : 398-410.

BRADFORD, J. M. 1970. Diurnal variation in vertical distribution of pelagic copepods off Kaikoura, New Zealand. N.Z.J1.mar. Freshwat. Res., $4(4): 337-350$.

BUZAS, M. A. 1969. Foraminiferal species densities and environmental variables in an estuary. Limnol. Oceanogr.., 14:411-422.

1971. Analyses of species densities by the multivariate general linear model. Limnol. Oceanogr., 16: $667-670$.

CONOVER, R. J. 1956. Oceanography of Long Island Sound, 1952-1954. VI. Biology of Ácartia clausi and A. tonsa. Bull. Bingham oceanogr. Coll., 15: 156-233.

CUSHING, D. H. 1951. The vertical migration of planktonic crustaceans . Biol. Rev., 26(2):158-192.

DARO, M. H. 1974. Etude des migrations nyctemerales du zooplancton dans un milieu marin peu profond. Hydrobiologia, 44(2-3) :149-160.

DEVASUNDARAM, M. P. \& ROY, J. C. 1954 . A preliminary study of the plankton of the Chilka Lake for the years 1950 \& 1951. FAO/UNESCO, Symp. Mar. Freshw. Plankton in the Indo-Pacific, Bangkok, P. 48-54.

DIXON, W. J., ed. 1974. Biomedical computer programs. Berkeley, Univ. California Press, 773 p.

ENRIGHT, J. T. \& HAMMER, W. M. 1967. Vertical migrations and endogenous rhythmicity. Science, N. Y., $157(3791): 937-941$.

FERNANDEZ, F. da C. 1977. Contribuição à ecologia dos bivalves do infrali- toral de fundos moles da região de Ubatuba (São Paulo). Dissertação de mestrado. Universidade de São Paulo, Instituto Oceanográfico, 70 p.

FURUHASHI, K. 1976. Diel vertical migration suspected in some copepods and chaetognaths in the inlet waters, with a special reference to behavioural differences between male and female, noted in the former. Publs Seto mar. biol. Lab., 22(6):355-370.

GLOVER; R. S. \& POPE, J. A. 1956. The Hardy plankton indicator: a study of the variation between catches taken by day and by night. Bu11. mar. Ecol., $4(32): 115-134$.

GRICE, G. D. 1960. Calanoid and cyclopoid copepods collected from the Florida Gulf Coast and Florida Keys in 1954 and 1955. Bul1. mar. Sci. Gulf Caribb., 10(2):217-226.

GRINDLEY, J.R. 1972. The vertical migration behaviour of estuarine plankton. Zoo1. afr., 7(1):13-20.

1977. The zooplankton of Langebaan Lagoon and Sandanha Bay. Trans. R. Soc. S. Afr., 42(3-4):341370 .

GURNEY, R. 1927. Copepoda and Cladocera of the plankton. Trans. zool. Soc. Lond., 22:139-172.

HODGKISS, I. J. 1977. The use of simultaneous sampling bottle and vertical net collections to describe the dynamics of a zooplankton population. Hydrobiologia, $52(2-3)$ :197-205.

HOFFMANN, R. \& VIEIRA, S. 1977. Anālise de regressão, uma introduçaõ à Econometria. São Paulo, HUCITEC/EDUSP, $339 \mathrm{p}$.

JACOBS, J. 1968. Animal behaviour and water movement as co-determinants of plankton distribution in a tidal system. Sarsia, 34:355-370.

JIMENEZ, A., M. P. 1976. Distribuição vertical e estádios de desenvolvimento de Lucifer faxoni Borradaile (Crustacea) ao largo de Santos. Dissertação de mestrado. Universidade de São Paulo, Instituto de Biociências, $54 \mathrm{p}$.

LANCE, J. 1962. Effects of water of reduced salinity on the vertical migration of zooplankton. J. mar. biol. Ass. U. K., 42:131-154.

1964. The salinity tolerance 
of some estuarine planktonic crustaceans. Biol. Bull. mar. biol. Lab. Woods Hole, 127(1):108-118.

LAWSON, T. L. \& GRTCE, G. D. 1973. The developmental stages of Paracalanus crassirostris Dah1, 1894 (Copepoda; Calanoidea). Crustaceana, 24:43-56.

LEWIS, A. G. 1959. The vertical distribution of some inshore copepods in relation to experimentally produced conditions of light and temperature. Bull. mar. Sci. Gulf Caribb., 9:6978 .

LONGHURST, A. R. 1976. Vertical migration. In: Cushing, D. H. \& Walsh, J. J., eds. - The ecology of the seas. Oxford, Blackwe11, p. 116137.

MARLOWE, C. F. \& MILLER, C. B. 1975. Patterns of vertical distribution of zooplankton at ocean station "P". Limno1. Oceanogr., 20(5):824-844.

MILSTEIN, A., Paracalanus crassirostris (Copepoda: Calanoidea): variations of its abundance in a shallow water station. Anais Acad. bras. Ciênc., Sup1. (no prelo)

MOORE, H.B. 19j3. Plankton of the Florida Curzent. II. Siphonophora. Bull. mar. Sci. Gulf Caribb., 2(4): 559-573.

\section{Variations in}

temperature and light response within a plankton population. Biol. Bull. mar. biol. Lab. Woods Hole, 108(2): 175-181.

\& BAUER, J. C. 1960. An analysis of the relation of the vertic distribution of three copepods to nvironmental conditions. Bul1. mar. Sci. Gulf Caribb., 10(4): 430-443.

i COR'NIN, E. G. 1956. The effects of temperature, illumination and pressure on the vertical distribution of zoop1.ankton. Bull. mar. Sci. Gulf Caribb., 6(4).273-287.

$$
\text { \& O'BERRY, D. F. } 1957 .
$$

Plankton of the Florida Current. IV. Factors influencing the vertical distribution of some common copepods. Bull. mar. Sci. Gulf Caribb., 7 (4): 287-315.

T OWRE, H.; JONES,

Current. III. The control of the vertical distribution of the zooplankton in the daytime by light and temperature. Bull. mar. Sci. Gulf Caribb., 3(2):83-95.

MOREIRA, M. G. S. 1973. On the diurnal vertical. migration of Hydromedusae off Santos, Brazil. Publs seto mar. bio1. Lab., 20:537-566.

1976. Sobre a migração vertical diária do plâncton ao largo de Santos, Estado de São Paulo, Brasil. Bolm Inst. oceanogr., S Paulo, 25 (1):55-76.

PE.ARCY, W. G.; KRYGIER, E. E.; MESECAR, R. \& RAMSEY, F. 1977. Vertical distribution and migration of oceanic micronekton off Oregon. Deep-sea Res., 24(3):223-246.

PILLAI, P. P. \& PILLAI, M. A. 1973. Tidal influence on the diel variation of zooplankton with special reference to copepods in the Cochin Backwater. J. mar. biol. Ass. India, $15(1): 411-417$.

PIRES, A. M. S. 1977. Aspectos ecológicos da fauna de Isopoda (Crustacea: Peracarida) das zonas litoral e infralitoral de fundos duros da Enseada do Flamengo, Ubatuba, São Paulo. Tese de Doutorado. Universidade de São Paulo, Instituto Oceanográfico, $83 \mathrm{p}$.

ROCHA, C. E. F. da 1977. Distribuição dos Cladocera e Ostracoda (Crustacea) planctônicos marinhos ao largo de Santos, Brasil. Dissertação de Mestrado. Universidade de São Paulo, Instituto de Biociências, 100 p.

RUDYAKOV, Yu. A. 1971. Details of the horizontal distribution and diurnal vertical migrations of Cypridina (Pyrocypris) sinuosa (G. W. Müller) (Crustacea, Ostracoda) in the western equatorial Pacific. In: Vinogradov, M. E., ed. - Life activity of pelagic communities in the ocean tropics. Jerusalem, Israel Program for Scientific Translations, p. 240-255.

RUSSELL, F. S., 1927. The vertical distribution of plankton in the sea. Biol. Rev., 2:213-262.

SAMEOTO, D. D. 1975. Tidal and diurnal effects on zooplankton sample variability in a nearshore marine environ- 
ment. J. Fish. Res. Bd Can., 32(3): 347-366.

SCHAEFFER-NOVELLI, Y. 1976. A1guns aspectos ecológicos e análise da população de Anomalocardia brasiliana (Gmeiin, 1791) Mollusca, Bivalvia, na praia do Saco da Ribeira, Ubatuba, Estado de São Paulo. Tese de Doutorado. Universidade de São Paulo, Instịtuto de Biociências, $118 \mathrm{p}$.

SEAL, H, L. 1966. Multivariate statistical analysis for biologists. London, Methuen, $207 \mathrm{p}$.

SEWELL, R. B. S. 1948. The free-swimming planktonic Copepoda. Geographical distributicn. Scient. Rep. John Murray Exp., 8(3):317-592.

STICKNEY, R. R. \& KNOWLES, S. C. 1975. Summer zooplankton distribution in a Georgia estuary. Mar. Biol., 33(2): 147-157.
TEIXFIRA, C. 1973. Preliminury studies of primary production in the Ubatuba region (Lat. $23^{\circ} 30^{\prime} \mathrm{S}$ - Long. $45^{\circ} 06^{\prime} \mathrm{W}$ ), Brazil. Bolm Inst. oceanogr., S Paulo, $22: 49-58$.

1965 ; TUNDISI, J. \& KUTNER, M. B . 1965. Plankton studies in a mangrove environment. II. The standing-stock and some ecological factors. Bolm Inst. oceanogr., S Paulo, 14(1):13-41.

TUNDISI, T. M. 1972. Aspectos ecolögi$\cos$ do zooplâncton da região lagunar de Cananéia com espccial refezência aos Copepoda (Crustacea). Tese de Doutcrado. Universidade de São Paulo, Instituto de Biociências, $191 \mathrm{p}$.

VINOGRADOV, M. E. 1970. Vertical distribution of the oceanis zooplankton. Jerusalem, Israel Program for Scientific Translations, $339 \mathrm{p}$.

YAMAZI, I. 1957. Plankton investigation in inlet waters a? ong the coast of Japan. XX. Diurnal change of plankton anımals at an innermost station in Wakayama Harbour. Publs Seto mar. biol. Lab., 6(2):209-224.

(Received July 24, 1978) 